\title{
A Review- Microstrip Patch Antenna Design
}

\author{
${\text { Gurpreet } \text { Kaur }^{1} \text {, Er. Sonia Goyal }}^{2}$ \\ ${ }^{1,2}$ (Department of Electronics and Communication Engineering/ Punjabi university patiala, India)
}

\begin{abstract}
Micro strip patch antennas are widely used in compact, conformal and low-cost wireless applications due to its advantages over conventional antenna. Literature study of last few decades of micro strip patch antenna (MPA) shows that the different techniques are used to design a small size micro strip patch antenna. In this paper survey is conducted on different antenna designing methods like E shaped patch antenna, edge tapering slot cutting, $G$ shapes, $H$ shape, Fractal geometry and DGS.These antennas operated on single band, dual band,multiband and UWB frequencies. The maximum gain achieved is $7.5 \mathrm{~dB}$ using $G$ - shape and return loss -28 dB by using E-shape technique.
\end{abstract}

Keywords: Bandwidth enhancement, Fractal geometry, slot antenna, HFSS, Micro strip patch antenna (MPA), edge tapering.

\section{INTRODUCTION}

An antenna is a very important device in wireless applications. It converts the electrical energy into RF signal at the transmitter and RF signal into electrical energy at the receiver side. A micro strip antenna consists of a rectangular patch on a ground plane separated by dielectric substrate [1]. The patch in the antenna is made of a conducting material $\mathrm{Cu}$ (Copper) or $\mathrm{Au}$ (Gold) and this can be in any shape of rectangular, circular, triangular, elliptical or some other common shape. In basic form, a Micro strip Patch antenna as shown in fig 1 consists of a radiating patch on one side of a dielectric substrate which has a ground plane on the other side. The radiating patch and the feed lines are usually photo etched on the dielectric substrate.

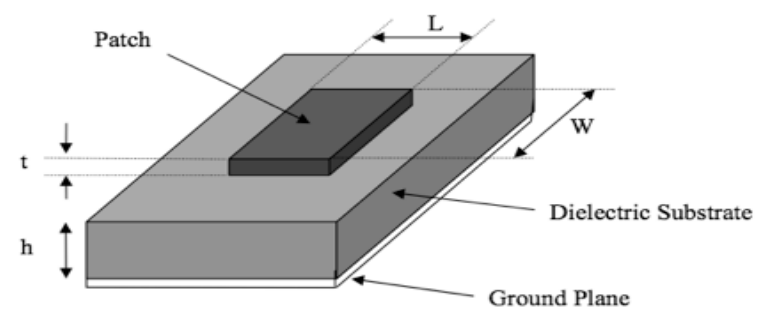

Fig.1: Micro strip Patch Antenna [9]

Micro strip antenna have a number of advantages which are small size, low profile, low weight but have a number of disadvantages like low bandwidth, low gain. Hence instead of improving this, fractal geometry has been applied on patch of antenna. Fractal geometry composed self-similar structure. Whenever fractal geometry is applied cuts are made on patch which causes current flow direction change to occur. Hence antenna resonates at different frequency bands. There are a number of bands at which antenna may operate. These bands are $\mathrm{L}, \mathrm{S}$, and $\mathrm{C}$ and $\mathrm{X}$ band. Whenever fractal geometry is applied, antenna can be useful for number of applications like GPS, satellite, communication, GSM, satellite and Radar. There are different fractals geometries that can be used but most commonly used geometry are Minkowski, Koch, and cantor shape. Further with increase in number of iterations, size of antenna decreases. By providing a number of slots over the patch, bandwidth is improved of patch antenna. Due to presence of multiple slots, $\mathrm{Q}$ factor decreases and value of patch inductance increases. By the decrease in $\mathrm{Q}$ factor, the bandwidth (BW) of patch antenna is increased accordingly,

$$
\text { Bandwidth, BW [9] }=\frac{1}{Q \sqrt{2}}
$$

Where,

$$
\mathrm{Q}=\frac{R}{\omega 0 L} \quad \text { (2) [9] }
$$




\section{LITERATURE SURVEY}

R. K.Sharan et. al [2] proposed an edge tapered wideband rectangular patch antenna with one slot at the center and parasitic stubs on two sides of the patch. In this paper partial ground is used. The height of the ground is varied from $8.6 \mathrm{~mm}$ to $9.2 \mathrm{~mm}$ and their effect on return loss was measured. Also the effect of varying the length of parasitic stub was measured. Length was varied from 4 to $8 \mathrm{~mm}$. This antenna was designed for wideband applications having bandwidth of $112 \%$.This antenna also have good radiation pattern with a gain of $2.65 \mathrm{~dB}$ and having $83.9 \%$ radiation efficiency. The overall dimension of the antenna is $35 \times 35 \times 1.6 \mathrm{~mm}^{3}$.

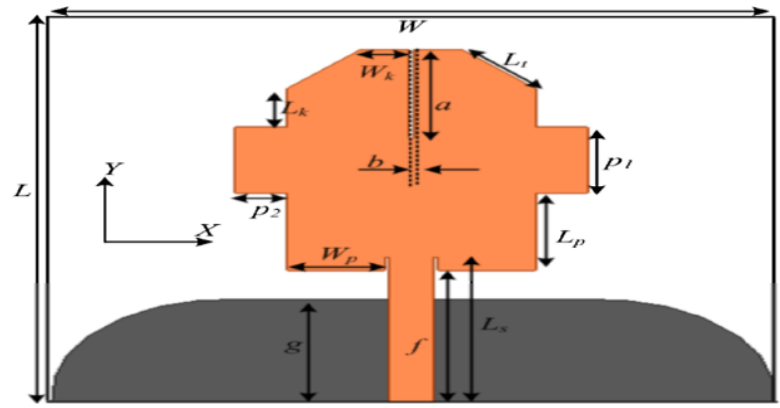

Fig.2: 2D View of Proposed Antenna With Slot And Parasitic Stub [All Dimensions Are In Mm: L= 35, W = 35, A = 8, B = $0.2, \mathrm{~F}=12, \mathrm{G}=9.4, \mathrm{~L}_{\mathrm{s}}=13.2, \mathrm{~W}_{\mathrm{p}}=4.175, \mathrm{~L}_{\mathrm{p}}=7, \mathrm{~L}_{\mathrm{k}}=3.5, \mathrm{~W}_{\mathrm{k}}=2.4, \mathrm{~L}_{\mathrm{t}}=4.95, \mathrm{P}_{1}=6, \mathrm{P}_{2}=2.5[1]$

In this paper, rectangular patch antenna is designed by using parasitic stubs and slot. To eliminate stray electric field, remove the upper two corners of patch by using edge tapering. It provides greater bandwidth than conventional antenna [10,11].The proposed antenna is implemented and fabricated on FR4 Epoxy Glass substrate (er $=4.4)$ with thickness of $1.6 \mathrm{~mm}$.

K.Sankar et. al [3] proposed a circularly proposed dual band single layer G-Shaped patch antenna with using HFSS. By using four slots on patch antenna he designed a G shape on patch. Micro strip antenna has limited bandwidth due to resonance behavior. To increase the radiation and bandwidth, shape of patch can be changed by creating slots on it. The main idea behind this is to provide two resonance frequencies. These frequencies are $3 \mathrm{GHz}$ and $3.8 \mathrm{GHz}$. At $3 \mathrm{GHz}$ frequency achieved gain and return loss are $7.5 \mathrm{~dB}$ and $-17 \mathrm{~dB}$ and at $3.8 \mathrm{GHz}$ gain and return loss are $2.4 \mathrm{~dB}$ and $-15 \mathrm{~dB}$.

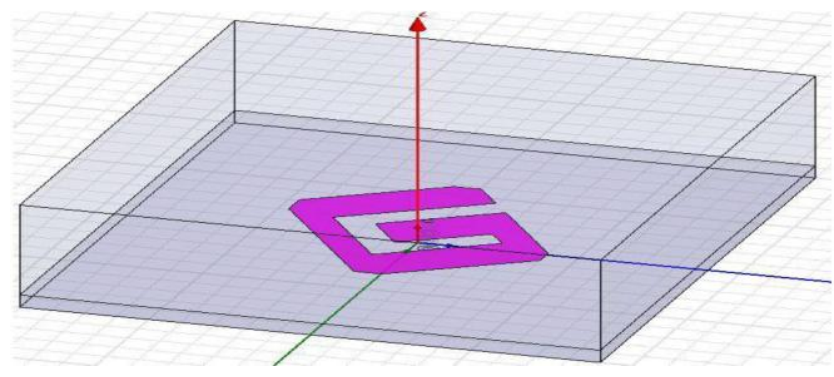

Fig. 3.Design of G- Shape Patch Antenna in HFSS [2]

Reza Zaker et. al [4] proposed a novel modified micro strip -fed ultra-wideband (UWB) planar monopole antenna with variable frequency band-notch function. In this design bandwidth magnification can be done by putting two slots in the both sides of micro strip feed line on the ground plane. This antenna is constructed using FR4 substrate with thickness of $1.0 \mathrm{~mm}$ with dielectric constant of 4.4. The additional current path can be provided by cutting slots and this also change the inductance and conductance of input impedance which changes the bandwidth. A modified $\mathrm{H}$-shaped conductor-backed plane with variable dimensions is used in order to generate the frequency band-stop performance and control its characteristics such as band-notch frequency and its bandwidth. By changing the shape and size of slot, the resonant character of structure transmission with resonant frequency can be controlled. The designed antenna has a small size of $22 \times 22 \mathrm{~mm}^{2}$ and operates over the 
frequency band between 3.1 and $13.9 \mathrm{GHz}$ for VSWR <2 with band rejection performance in the frequency band of 5.1 to $5.9 \mathrm{GHz}$.

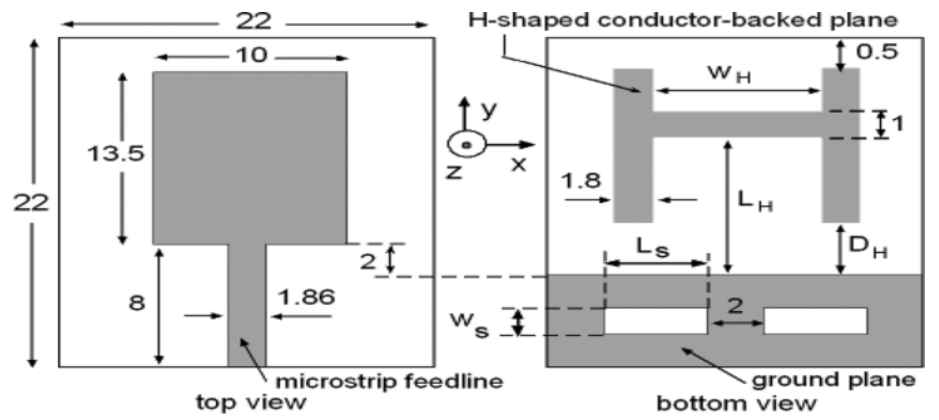

Fig.4. Geometry of the Proposed Planar Monopole Antenna (Unit: Mm) [3]

Subhrakanta Behera et. al [5] proposed a Multiport network approach for the analysis of dual band fractal micro strip antennas . To analyze the behavior of micro strip fractal antenna, multiport network approach is used. It has been observed that by increasing the indentation factor in the fractal section of the radiator, the resonance frequencies of the antenna changes and by suitably choosing this value one can get an antenna design with improved bandwidth with good gain at both the resonance frequencies. .

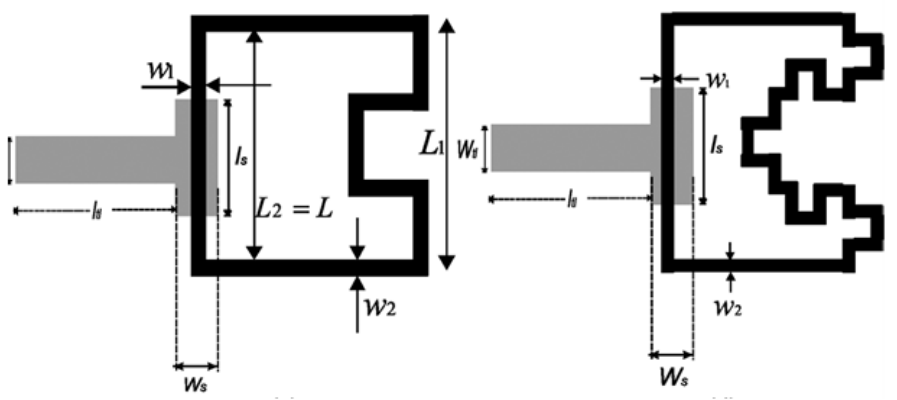

(a)

(b)

Fig.5. (a) Antenna with 1st iteration fractal. (b) Antenna with $2^{\text {nd }}$ iteration fractal [4]

In this paper the length opposite to the feed line replaced with Minkowski geometry. In the 1si iteration center part of the line gets removed and parameters of the antenna like gain, return loss and radiation pattern was calculated. In $2^{\text {nd }}$ iteration same process was repeated and the patch shape becomes as shown in fig5 (b). Ground plane used a dimension of $20 \times 20 \mathrm{~cm}^{2}$ using aluminum materials. This antenna was designed in IE3D software. By using iteration the bandwidth of antenna get increased.

R. Ghatak et. al [6] proposed a wideband fractal shaped slot antennas for X-band application. A novel fractal patterned iris loaded cross dipole slot antenna along broad wall of rectangular waveguide at $\mathrm{X}$ - band is designed. To improve the impedance matching, the method of junction tapering of the cross slots is used. Bandwidth improvement is $t$ better than $2 \mathrm{GHz}$ with optimization of iris depth and inclusion of a second iteration slot in the vicinity of the primary cross slot. Peak realized gain remains around $7 \mathrm{~dB}$ over the operational bandwidth.

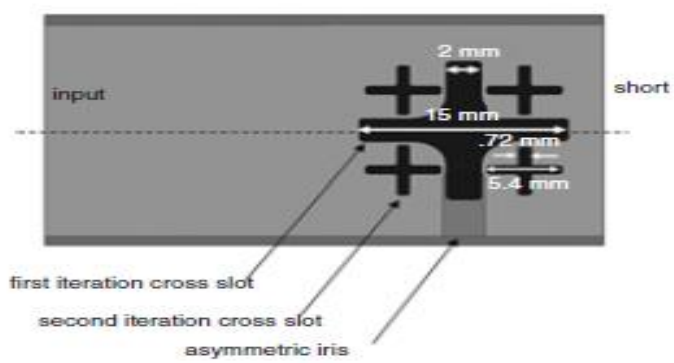

Fig.6. Structural layout [5] 
A pattern and impedance bandwidth better than $2 \mathrm{GHz}(9.6$ to $12 \mathrm{GHz})$ is calculated with a second iteration cross dipole fractal shape centered slot antenna loaded with a curved partial height iris of $4 \mathrm{~mm}$ thickness and $7.2 \mathrm{~mm}$ depth [6].

Ajay Yadav et. al.[7] represent a design \& analysis of E-shape micro strip patch antenna for wireless communication. The benefits of this antenna were decrease in volume, low profile configuration, smoothly mounted, light weight, less production cost. The antenna operate on $3.1 \mathrm{GHz}$ and $3.45 \mathrm{GHz}$ frequencies. This antenna was implemented by using FR4 substrate with dielectric constant 4.2 and thickness of $1.6 \mathrm{~mm}$. To enhance the bandwidth two parallel slots were cut which provide additional current path. To achieve the desired output parameters, the dimensions of patch and ground can also be changed [12-15]. It has been detected that the position of feed points effect the behavior of the designed antenna. The return loss of $-12 \mathrm{~dB}$ of and $-28 \mathrm{~dB}$ at operating frequencies $3.1 \mathrm{GHz}$ and $3.45 \mathrm{GHz}$ respectively were calculated using this design. To simulate the results of designed antenna HFSS software was used.

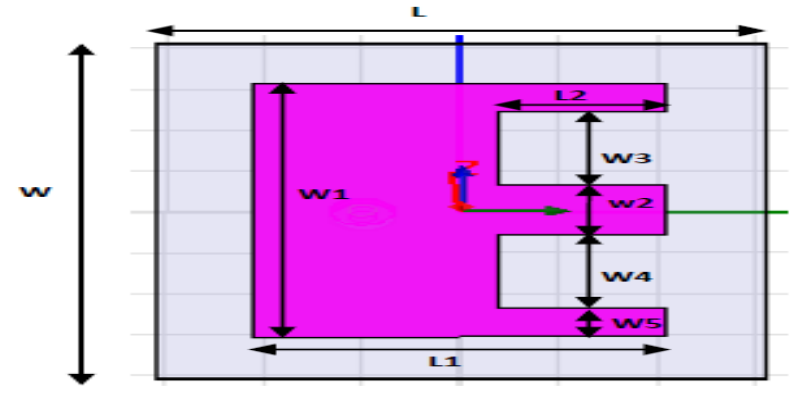

Fig.7. Design of Proposed Antenna (Top View) [6]

Table 1: Table for the Comparative Analysis of Different Techniques.

\begin{tabular}{|c|c|c|c|c|}
\hline Sr. No & Title & Technique & Input parameter & Output parameter \\
\hline 1 & $\begin{array}{l}\text { An Edge } \\
\text { Rectangular } \\
\text { Antenna with Parasitic } \\
\text { Stubs and Slot for } \\
\text { Wideband Applications } \\
{[1]}\end{array}$ & $\begin{array}{l}\text { A rectangular patch } \\
\text { antenna with tapered edge } \\
\text { was designed. The slot } \\
\text { and parasitic stubs were } \\
\text { also used for this design. }\end{array}$ & $\begin{array}{l}\text { FR4 Epoxy Glass } \\
\text { was used as substrate } \\
\text { with thickness of } 1.6 \\
\text { mm } \\
\text { Dielectric constant } \\
\text { of substrate }=4.4 \\
\text { Antenna size }=35 \quad \times \\
35 \times 1.6 \mathrm{~mm}^{3} .\end{array}$ & $\begin{array}{l}\text { Percentage } \\
\text { Bandwidth }=112 \% \\
\text { (centered at } 6.01 \\
\text { GHz) } \\
\text { Average radiation } \\
\text { efficiency }=83.9 \%\end{array}$ \\
\hline 2 & $\begin{array}{l}\text { Single Layer Dual band } \\
\text { G-shaped } \\
\text { antenna[2] }\end{array}$ & $\begin{array}{l}\text { A G- shape slot was cut } \\
\text { on the patch for } \\
\text { bandwidth magnification. }\end{array}$ & $\begin{array}{l}\text { Dielectric constant } \\
=2.2 \\
\text { Substrate } \\
=4 \mathrm{~mm} \\
\text { Patch lhickness } \\
=30 \mathrm{~mm} \\
\text { Patch } \\
=40 \mathrm{~mm}\end{array}$ & $\begin{array}{l}\text { At frequency } 3 \mathrm{GHz} \\
\mathrm{BW}=500 \mathrm{MHz} \\
\mathrm{Gain}=7.5 \mathrm{dBi} \\
\text { Return loss }=-17 \mathrm{dBi} \\
\mathrm{At} \text { frequency } \\
\mathrm{GHz} \\
\mathrm{BW}=400 \mathrm{MHz} \\
\text { Gain }=2.4 \mathrm{dBi} \\
\text { Return loss }=-15 \mathrm{dBi}\end{array}$ \\
\hline 3 & $\begin{array}{l}\text { Novel Modified UWB } \\
\text { Planar Monopole Antenna } \\
\text { With Variable Frequency } \\
\text { Band-Notch Function [3] }\end{array}$ & $\begin{array}{l}\text { In this paper H- shape } \\
\text { was designed on patch } \\
\text { antenna and also two } \\
\text { square slots are inserted } \\
\text { on ground plane. This } \\
\text { DGS provide an } \\
\text { additional current path. }\end{array}$ & $\begin{array}{l}\text { Ground- } 22 \times 22 \mathrm{~mm}^{2} \\
\text { Patch length- } 13.5 \mathrm{~mm} \\
\text { Patch width }-10 \mathrm{~mm} \\
\text { feed line length- } 8 \mathrm{~mm} \\
\text { Feed line width- } \\
1.86 \mathrm{~mm}\end{array}$ & $\begin{array}{l}(\mathrm{VSWR}<2) \text { for } \\
\text { frequency band of } 3.1 \\
\text { to over } 13.9 \mathrm{GHz} \\
\text { with rejection band } \\
\text { around } 5.1 \text { to } 6 \mathrm{GHz} \text {. }\end{array}$ \\
\hline 4 & Multi-Port & Minkowski & Ground & At first iteration \\
\hline
\end{tabular}




\begin{tabular}{|c|c|c|c|c|}
\hline & $\begin{array}{l}\text { Approach for the Analysis } \\
\text { of Dual Band Fractal } \\
\text { Micro strip Antennas [4] }\end{array}$ & $\begin{array}{l}\text { geometry was used. In } \\
\text { Minkowski initiator is } \\
\text { divided into three equal } \\
\text { parts of length and by two } \\
\text { horizontal and a vertical } \\
\text { segment of equal length } \\
\text { middle segment was } \\
\text { replaced. }\end{array}$ & $\begin{array}{l}\text { aluminium } r \\
\text { dimensions } 20 \mathrm{~cm} \times \\
20 \mathrm{~cm} \text { was used. }\end{array}$ & $\begin{array}{l}\mathrm{F}_{\mathrm{r} 1}=2.95 \mathrm{GHz} \\
\mathrm{BW}=38 \mathrm{MHz} \\
\text { Gain }=5.98 \mathrm{dBi} \\
\text { At } 2^{\text {nd }} \text { iteration } \\
\mathrm{F}_{\mathrm{r} 2}=4.725 \mathrm{GHz} \\
\mathrm{BW}=59.8 \mathrm{MHz} \\
\text { Gain }=5.3 \mathrm{dBi}\end{array}$ \\
\hline 5 & $\begin{array}{l}\text { Wideband fractal shaped } \\
\text { slot antenna for X-band } \\
\text { application [5] }\end{array}$ & $\begin{array}{l}\text { Fractal geometry was } \\
\text { used. A second iteration } \\
\text { fractal shaped cross slot is } \\
\text { fabricated along the } \\
\text { centre of the broadwall of } \\
\text { a rectangular waveguide. }\end{array}$ & $\begin{array}{l}\text { At } 1^{\text {st }} \text { iteration length } \\
\text { and width of }+ \text { sign } \\
\text { was } 15 \mathrm{~mm} \text { and } 2 \mathrm{~mm} \text {. } \\
\text { At } 2^{\text {nd }} \text { iteration length } \\
\text { and width of }+ \text { sign } \\
\text { was } 5.4 \mathrm{~mm} \text { and } \\
72 \mathrm{~mm} \text {. }\end{array}$ & 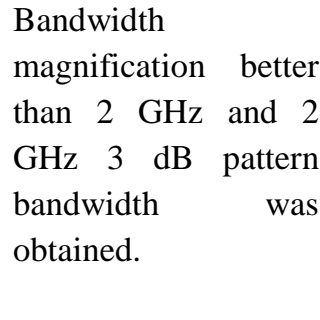 \\
\hline 6 & $\begin{array}{l}\text { Micro strip Symmetrical } \\
\text { E-Shape Patch } \\
\text { for the }\end{array}$ & $\begin{array}{l}\text { E shape antenna was } \\
\text { designed by cutting two } \\
\text { slots from rectangular } \\
\text { patch. }\end{array}$ & $\begin{array}{l}\text { Resonant frequency } \\
\text { fr } 3.1 \mathrm{GHz} \text { co-axial } \\
\text { feed line was used. } \\
\text { Ground plane- } 41 \times 31 \\
\mathrm{~mm}^{2} \\
\text { Patch- } 31 \times 21 \mathrm{~mm}^{2}\end{array}$ & $\begin{array}{l}\text { Gain }=4.7 \mathrm{~dB} \\
\text { Return loss }=-28 \mathrm{~dB}\end{array}$ \\
\hline
\end{tabular}

\section{ANTENNA DESIGN}

Step 1: The width of the micro strip patch antenna is calculated by equation (3)

$$
W=\frac{\lambda_{0}}{f_{o} \sqrt{\left(\epsilon_{r}+1\right) / 2}}
$$

Step 2: Determine effective dielectric constant, $\varepsilon_{\text {reff }}$, [8] using equation (4)

$$
\varepsilon_{\mathrm{reff}}=\frac{\left(\varepsilon_{\mathrm{r}}+1\right)}{2}+\frac{\left(\varepsilon_{\mathrm{r}}-1\right)}{2}\left[1+12 \frac{\mathrm{h}}{\mathrm{W}}\right]^{-\frac{1}{2}}
$$

Step 3: Calculate the length extension $\Delta \mathrm{L},[8]$ using equation (5)

$$
\frac{\Delta \mathrm{L}}{\mathrm{h}}=0.412 \frac{\left(\varepsilon_{\text {reff }}+0.3\right)\left(\frac{\mathrm{W}}{\mathrm{h}}+0.264\right)}{\left(\varepsilon_{\text {reff }}-0.258\right)\left(\frac{\mathrm{W}}{\mathrm{h}}+0.8\right)}
$$

Step 4: Determine the patch length [8] by using equation (6)

$$
\mathrm{L}=\frac{\lambda_{0}}{f_{o} \sqrt{\epsilon_{\text {reff }}}}-2 \Delta L
$$

Where the effective length of the patch $\mathrm{L}_{\text {eff }}$

$$
L_{e f f}=\frac{\lambda_{0}}{f_{o} \sqrt{\epsilon_{\text {reff }}}}
$$

Step 5: Now calculate the dimensions of ground [8]

$$
\begin{gathered}
L_{g}=6 h+L \\
W_{g}=6 h+W
\end{gathered}
$$




\section{CONCLUSION}

This study provided an insight on determine the behavior of micro strip patch antenna using several designing techniques such as fractal, $\mathrm{G}$ shape, $\mathrm{E}$ shape, cross dipole slot, parasitic stub and edge tapering. The limitations of conventional antenna can be overcome by using the above mention techniques. The maximum value of output parameters gain by using G- shape technique and return loss by using E- shape technique are $7.5 \mathrm{~dB}$ and $-28 \mathrm{~dB}$. The techniques discussed in this paper are based on HFSS to simulate the various parameters of antenna.

\section{REFERENCES}

[1] Balanis A Constantine, Antenna theory (New York, John wiley \& sons, Inc 1997).

[2] R.K. sharan, S.K. Sharma, A .Gupta, R.K Chaoudhary, An Edge Tapered Rectangular Patch Antenna with Parasitic Stubs and Slot for Wideband Applications, Wireless Pers Commun Vol 86,2016, pp 1213-1220.

[3] K.Sankar,R.Bargavi, and S.Arivumani Samson, Single Layer Dual band G-shaped patch antenna, International Conference on Communication and Signal Processing, 2014, pp-636-639.

[4] R. Zaker, C. Ghobadi, and J. Nourinia, Novel Modified UWB Planar Monopole Antenna With Variable Frequency Band-Notch Function, IEEE Antennas And Wireless Propagation Letters, Vol. 7, 2008 ,Pp-112-114.

[5] S Behera and K. J. Vinoy, Multi-Port Network Approach for the Analysis of Dual Band Fractal Microstrip Antennas, IEEE Transactions On Antennas And Propagation, Vol. 60, 2012 Pp-5100-5106

[6] R. Ghatak, S. Chatterjee and D.R. Poddar, Wideband fractal shaped slot antenna for X-band application, Electronics Letters Vol. 48, 2012.

[7] A. Yadav, B.Chauhan, A. Jain, Microstrip Symmetrical E-Shape Patch Antenna for the Wireless Communication Systems, International Journal of Emerging Technology and Advanced Engineering Volume 2, Issue 12, 2012,pp 241-244.

[8] M. A. Afridi, Microstrip Patch Antenna - Designing at 2.4 GHz Frequency, Biological and Chemical Research, Vol.6, 2015, pp-128132

[9] Parvathy P. Chandran, Mr. Sanoj Viswasom, Gain and Bandwidth optimization of Microstrip Patch antenna, 2014 Fourth International Conference on Advances in Computing and Comunications.

[10] Malekpoor, H., \& Jam, S. (2013). Miniaturised asymmetric E-shaped microstrip patch antenna with folded-patch feed. ET Microwaves, Antennas and Propagation, 7, 85-91.

[11] Ansari, J. A., Kumari, K., Singh, A., \& Mishra, A. (2013). Ultra wideband co-planer microstrip patch antenna for wireless applications. Wireless Personal Communications, 69, 1-14.

[12] Subodh Kumar Tripathi and Vinay Kumar, E-Shaped Slotted Micro strip Antenna with Enhanced Gain for Wireless Communicationll, IEEE Transactions on Antenna \& propagation July to August 2011.

[13 ] B.-K. Ang and B.-K. Chung, A Wideband E-Shaped microstrip patch antenna for 5-6 GHz wireless communicationsl, Progress In Electromagnetics Research, PIER 75, 397-407, 2007

[ 14] G.Purnachandra Rao, Kshitiz Agarwal, M.V.Kartikeyan and M.K.Thumm, - Wideband signal patch E-shaped compact micro strip antenna for high speed wireless local area networks\| IEEE Transactions on Antenna \& propagation

[15] M.K.verma, Sapna Verma, and D.C.Dhubkarya, -Analysis and designing of E-shape micro strip patch antenna for wireless communication systeml, IEEE Transactions on Emerging Trends in Electronic and Photonic Devices \& Systems, 2009 